\title{
Representations of western Amazonian indians on Inca colonial qeros
}

\author{
Cristiana Bertazoni*
}

\begin{abstract}
BERTAZONI, C. Representations of western Amazonian indians on Inca colonial
\end{abstract} qeros. Revista do Museu de Arqueologia e Etnologia, São Paulo, 17: 321-331, 2007.

Resumo: Este artigo propõe uma análise iconográfica dos vasos coloniais Inca conhecidos como qeros, oferecendo, dessa forma, uma visão da história Inca em que pode ser observado um dos meios de expressão que os Incas utilizavam para disseminar seus valores, tradições e, em última instância, sua ideologia. Um expressivo número de qeros retrata cenas de batalhas entre Incas e índios da Amazônia ocidental (ou Antis), repetidamente retratando a fauna e flora amazônica. A análise iconográfica dos qeros sugere que dos quatro suyus do império, o Antisuyu (a parte amazônica do Tahuantinsuyu) é a região de maior relevância no que se refere às imagens representadas. Assim sendo, serão analisados alguns qeros na tentativa de melhor compreender as imagens do Antisuyu e seus habitantes que os Incas escolheram projetar através desse meio de comunicação.

Unitermos: Incas - Antisuyu - Amazônia Ocidental - Vasos qeros.

W hether it was cheering either the Inca or the sun, toasting as a social activity to strengthen social bonds or celebrating the harvest, drinking certainly had a special and fundamental place in many Andean social, economical and religious activities. So too did the "Andean beer" or chich $a^{1}$ and the Inca wooden or metal vases that held this precious liquid so valued among the Incas.

These Inca ceremonial wooden vases are called qeros (or aquilla when made of metal,

(*) Pós-doutoranda do Museu de Arqueologia e Etnologia da Universidade de São Paulo, bolsa FAPESP. Centro de Estudos Mesoamericanos e Andinos da Universidade de São Paulo (CEMA-USP). cristiana@ambjorn.com (1) Chicha is a drink produced from the fermentation of maize and which was (and still is) very common and widespread throughout the Andes. either silver or gold) and fulfilled many purposes in Andean society in addition to their more practical and immediate purpose of holding drinks. Besides functioning as a vessel, it also served as a visual medium that acted on behalf of Inca propaganda as well as resistance during colonial times. ${ }^{2}$ As suggested by Flores Ochoa (1998: 20), these vases had a strong ideological importance within the Inca Empire and were

(2) In an interesting discussion, Cummins reminds us that beyond Inca propaganda, qeros were crucial for the maintenance of Inca culture during colonial times since the "[...] Incas needed to project for themselves a legitimate identity in relation to the Andean past [...] Without such a 'history', the Inca could not explain their existence to themselves or anyone else, and their rise to an Andean power would have been outside any common understanding and impossible to sustain” (2002: 59). 
used to establish social, political and religious relations, always with a significant ideological content.

In the following pages, we shall look closely at these particular objects which so often portray scenes of battles between Incas and Antis $^{3}$ and, sometimes, even take the shape of the heads of Amazonian inhabitants and jaguars.

On November $16^{\text {th }}, 1532$, a famous encounter described by so many chroniclers, both native and Spanish, took place in the town of Cajamarca, Peru. There, a memorable meeting took place between the Inca king and a Spanish conquistador. Facing each other were Inca Atahualpa on his royal litera, with thousands of unarmed followers behind him; and Pizarro on his horse, flanked by a few armed soldiers. In an act of hospitality, Atahualpa twice offered Pizarro a gold aquilla filled with chicha which was unexpectedly poured onto the ground by the foreigner. Puzzled by Pizarro's rejection, Atahualpa wondered how the Spaniard could dare decline such a sacred liquid offered by an Inca king. ${ }^{4}$ Pizarro, in turn, offered Atahualpa what he considered most sacred: the bible. However, from the Sapa Inca perspective - himself the expression of God on earth - the bible seemed like an

(3) The Quechua word Antis by itself is a general or collective name used to describe a great variety of ethnic groups living in the Antisuyu. Indeed, the term does not define only one, but many indigenous groups. Tahuantinsuyu, the land of four quarters, comprised Chinchaysuyu, Collasuyu, Condesuyu and Antisuyu, the last of which represented the Amazonian corner of the Inca Empire. Hence, we see the use of Antis as a general term to refer to those inhabiting the Antisuyu. Here the word Antis will be used synonymously with western Amazonian Indians, for example, the Piro, Ashaninka, Cashinahua, Shipibo,

Amuesha and Machiguenga among others.

(4) Destos Viracochas traxeron dos dellos unos yugan a my tio Ataguallpa, que a la sazon estava en Caxamarca, el qual los recibió muy bien y mando de bever al uno dellos con un vaso de oro de la bebida que nosotros usamos, el español en recibiéndolo de su mano lo derramó, de lo qual se enojó mucho mi tio, y después desto aquellos dos españoles le mostraran al dicho my tio una carta o libro o no sé qué, diziendo que aquella hera la quillca de Dios y del Rey e mi tio, como se sentio afrentado del derramar la chicha, que ansy se llama nuestra bebida, tomó la carta o lo que hera y arroj 'lo por ay, diziendo: Qué se yo que me dais ay? (Titu Cusi Yupanqui 1992 [1570]: 5). alien object with no significance within the Andean context whatsoever. Outraged by Pizarro's refusal of chicha and not recognising the bible as an element of importance within Inca culture, the king threw the sacred book away. What followed is well known: Pizarro used Atahualpa's act as a pretext to accuse the Inca Emperor of committing a serious offence to Christianity by throwing away the word of God, and with this, the Spanish had the perfect excuse for the kidnap and subsequent execution of the Inca king - the infiel according to the Europeans - even after the Incas had paid the ransom required by Pizarro.

As seen from the historical event described above, the Inca golden aquilla filled with chicha had at that specific moment, from an Inca perspective, a similar and parallel significance as the bible had for the Spanish. Both objects played an equal role in a decisive moment of Andean history and can be seen as a symbolic representation of a cultural clash which would only become deeper with time. In the same way that Pizarro was angry due to Atahualpa's failure to recognise the bible, Atahualpa felt offended by Pizarro's rejection of the aquilla filled with chicha. Many Spanish chroniclers wrote on this specific episode, always emphasising the moment when Atahualpa threw the bible on the ground and never seeming to recognise the significance of the drinking vase and the chicha offered to Pizarro.

Given the episode described above and the crucial role the golden aquilla performed, what exactly are these vases which held so much importance among the Incas and passed almost unnoticed by the Europeans, at least in the beginning of the conquest? What was the meaning, inside Inca culture, of raising qeros in order to drink, of cheering in order to celebrate something, honour someone important or

(5) As in many other historical events concerning Inca history, there are many versions of this historical meeting between Atahualpa and Pizarro; Titu Cusi Yupanqui being the only writer to emphasise the importance of Pizarro's refusal in accepting Atahualpa's drink and hospitality. All the Spanish chroniclers seem to give little importance to this side of the famous encounter. See also Cummins 2002. 
welcome a guest? And, essentially, why would these Inca wooden vases have any importance when investigating the Inca attitudes towards their western Amazonian territories?

Vases similar to the Inca qeros are not an Inca invention and their genealogy goes back at least to Mochica and Chimú, as well as the Tiahuanaco period when it acquired more complex developments (Flores Ochoa 1998: 4-11). Inca qeros and aquillas were present in many Andean rituals and celebrations, for instance, when honouring the Inca Emperor, when the Sapa Inca hosted a guest, when cheering in honour of the sun, celebrating the harvest, during the rituals of reciprocity, among many other occasions (Fig. 1). Its importance in Andean culture is fundamental and it could, for example, be placed among other objects valued by the Incas such as textiles. Besides, according to Cummins (2002: 1) so important were the qeros within Inca culture that they were passed from one generation to another.

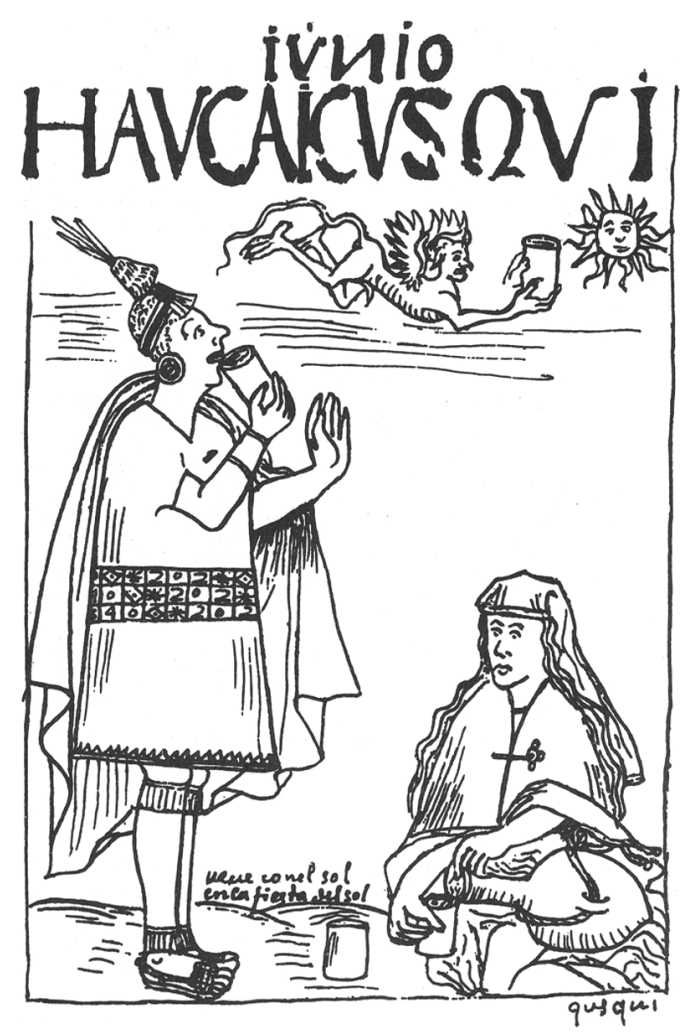

Fig. 1. Image showing two pairs of qeros. Source: Guaman Poma de Ayala (1980 [c. 1613]).
They were predominantly made in pairs, meaning that for every qero there was also another identical one, both in shape and imagery. Some authors have seen this dual quality of the qeros as a material representation of hanan and hurin, an Andean duality pattern that could be expanded to high and low, male and female and so forth (Cummins 1992). In addition, the fact they were made in pairs indicates their potential for creating social bonds between the two people (and the respective groups represented by them) drinking together from an identical pair of vases.

As for their physical qualities, most qeros are made of montaña wood (gold or silver in the case of aquillas, and a very tiny minority made of clay), ${ }^{6}$ which came mostly from the eastern slopes of the Andes, where an abundance of trees can be found (Cummins 2002: 23). Moreover, qeros did not have a plain surface, as they always came either painted or with incised engravings (or both), which suggests that besides fulfilling the immediate function of containing liquids, they also served as a medium where shapes, formats and images were crucial components with the potential to communicate and express ideas as well as to represent history.

While pre-Hispanic qeros tended to display geometrical designs and were strongly linked with Inca Imperial culture, it was only during colonial times that they gained a pictorial character (Rowe 1992), which illustrates a variety of figurative images such as animals,

(6) A qero made of clay has been found in a private collection of Tapajó pottery now held by the Museu de Arqueologia e Etnologia da Universidade de São Paulo. Since the collection lacks archaeological context, it is indeed hard to say whether the qero was included in the collection by its former owner or if it was found together with the Amazonian pottery on the archaeological site. If the latter is true, it is interesting that a vase from the Andean tradition should be found among Santarém ceramics in the very heart of the Amazon. In this case, it would probably either have been produced there according to Inca influences or, more likely, would have arrived there via the long distance webs of commerce established between highlands and lowlands Indians. A picture of this specific qero was published by Gomes (2002: 270). 
birds, flowers, plants as well as people and battle scenes. In his qero chronology, Rowe (1992) distinguishes between two periods of colonial qeros: archaic and late (or tardio). In the case of archaic wooden vases, the physical space that receives the paint is divided into four parts by rainbows emanating from feline mouths. In general, these geros show images of the Sapa Inca and coyas (Inca's wives). On the other hand, late colonial qeros display scenes of Inca history, myths and sometimes of colonial narrative. Among the imagery displayed on colonial qeros, one theme stands out from the rest given the high frequency in which they appear: representations of the Antisuyu and its inhabitants occur very often and proportionally with a much higher frequency than any other suyu or Tahuantinsuyu's quarter.

On investigating the multifaceted problem of the Antisuyu which permeates so many spheres and layers of Inca culture and manifests itself in several ways and formats such as plays, dances, rituals and images; one can observe the existence of numerous qeros images portraying Antis hunting with bows and arrows (Fig. 2), tropical forest animals, Amazonian wooden houses and, mainly, scenes of battles between Incas and Antis which are repeatedly represented on these Inca colonial vases. In addition, even more significant is the fact that no other ethnic group is represented anywhere near as often in battle scenes with the Incas - it is almost always only the Antis. Moreover, besides being so often represented on wooden vases, the Antisuyu also 'shaped' some qeros which are in the form of the heads of Antisuyu Indians. Alternatively, in a more indirect reference to the jungle, many qeros have handles in the form of a jaguar or are even in the shape of a jaguar's head itself.

Given these peculiarities found in both qeros' form and imagery, one may be tempted to enquire why exactly these wooden vases often portrayed icons and symbols which clearly refer to the Antisuyu, its inhabitants, its flora and fauna. Why do a significant number of qeros have the shape of the head

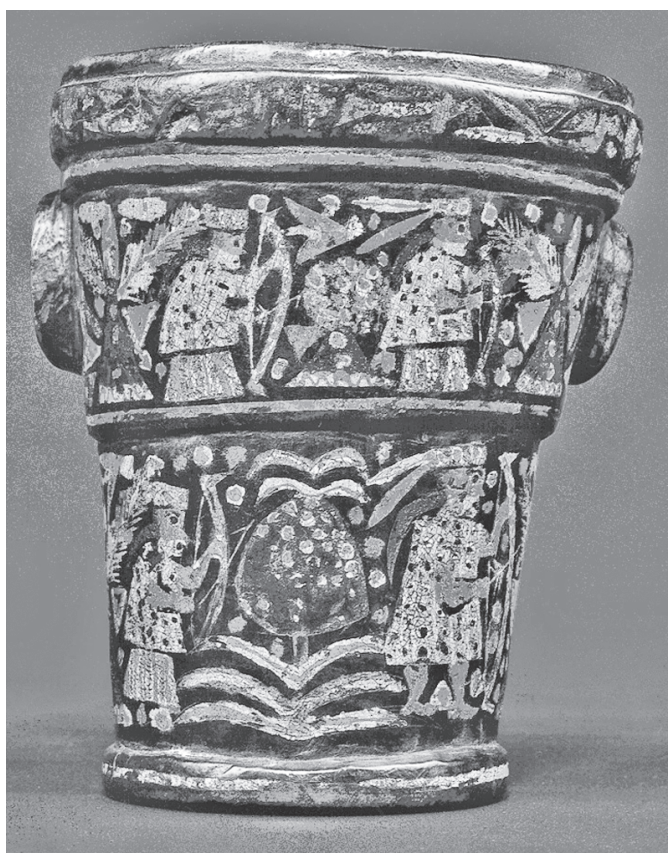

Fig. 2. Back of an anthropomorphic qero (shaped as an Anti's head) depicting Antisuyu hunters with bows and arrows. Source: Flores Ochoa; Arce; Argumedo (1998: 244).

of a jaguar or of Amazonian dwellers? Could this display of Antisuyu motifs be mere coincidence? Additionally, it seems that qerocamayocs (those specialising in qero making) were from the east of the Empire and until the present day, the communities that have adhered more strongly to the qeromaking tradition are also located to the east of Cuzco and even call themselves Q'eros (Cummins 2002: 24). Thus, did the qeros, its imagery and production have any special relationship with the Antisuyu and if they did, to what degree? Why are other suyus not represented on qeros in the same manner and regularity as the Antisuyu? Does this suggest that the Incas had a different relationship with their Amazonian territories?

If Cummins is correct (as I believe he is) that qeros and aquillas were Inca symbols of both reward and punishment or in his own words "promise and threat, in relation to order and disorder in Tawantinsuyu" (2002: 91), then the recurrent Antisuyu theme displayed 
on qeros could be understood as being a quintessential representation of the opposition/ reconciliation or rejection/admiration equation so often established between the Incas and the Antisuyu. ${ }^{?}$

Anyhow, in order to further and better understand these Antisuyu images on Inca colonial qeros, we shall analyse systematically two different types of vases on which the Antis were portrayed: firstly, the wooden vases displaying images of battle scenes between Incas and Antis, and secondly the qeros which acquired the head shape of either an Antisuyu Indian or a jaguar.

The scene of an Inca/Antis battle seems like a good starting point (Fig. 3). On a qero with a feline shaped handle, one sees that the left hand side of the image is populated by the Inca warriors, while the right hand side is filled with Anti combatants with painted faces (a typical Inca way of representing Indians from the forest). Numerous details and differences between these two groups can easily be identified. To start with, the Incas appear slightly taller than the Antis, signalling for the viewer a hierarchy where the Incas are doubtless in a superior position. In this image, many other elements suggest Inca superiority in relation to the Antis. For instance, the Incas wear helmets and have short hair, while the Antis wear a sort of hat and have long hair. According to Cummins (2002: 257), hair length is a very important attribute since it was an indication or a sign of social and political hierarchy among the Incas. Pizarro, for example, mentions that in Cuzco those who were sons of older brothers had short hair while the offspring of younger brothers were required to have longer hair. As can be observed from this image, besides the hierarchical oppositions of height and hair length, other elements reinforce this superiority/inferiority or Incas/Antis opposition discourse: the Incas wear tunics and hold their typical weapons while the Antis wear jaguar coat motifs and hold their bows and arrows. Here again, one identifies the presence of the quintessential jungle creature, the jaguar, or rather its skin being worn by Antis Indians which was seen to enable the warriors to acquire the strength and other qualities of the jaguar. The antagonism continues: at the far right, on the Inca side, a sunturhuasi ${ }^{8}$ can be seen; while on the Antis side, tropical animals such as a monkey and a parrot can be identified. It is worth noting that in the Antis part of the picture, human beings share the same space with tropical animals and plants, while on the Inca side, only people and the sunturhuasi can be identified. The idea of a symbiosis between the Antis and nature appears to be present in this image. In fact, in almost all images of the Antis - both those from Guaman Poma's manuscript or on the Inca colonial qeros - the Antisuyu Indians share the space with either animals or plants (or both). It is as if these elements are permanently associated with each other and one cannot be described without the other, as if Antis and nature were part of one and the same category. Moreover, this dichotomy reinforces the idea of a civilised Inca (reinforced in this particular image by the sunturhuasi) in opposition to the supposed lack of both technology and culture of the Antis, from an Inca perspective.

In summary, the whole image and all its constituent elements are part of one single discourse: Inca superiority over the Antis and its derivative elements such as hanan/hurin, male/female, and right/left, taller/shorter, high/low and so forth. Despite the battle in the image being frozen in time, and the apparent lack of a winner, a closer look based on the opposed elements mentioned above informs the attentive observer that there was only one winner: the superior, taller, shorter-haired, hanan Incas. Here, the Antis stood no chance of winning from the start. From this Inca
(7) For a detailed discussion on the Inca attitudes to the Antisuyu, see Saignes (1981, 1985); Renard-Casevitz (1988); Santos (1992); Taylor (1992, 1999) and Bertazoni (2007).
(8) According to Flores Ochoa (1998: 172), sunturhuasi are symbols of Inca Imperial power. It may be an architectural structure such as the one seen in the image in question. 


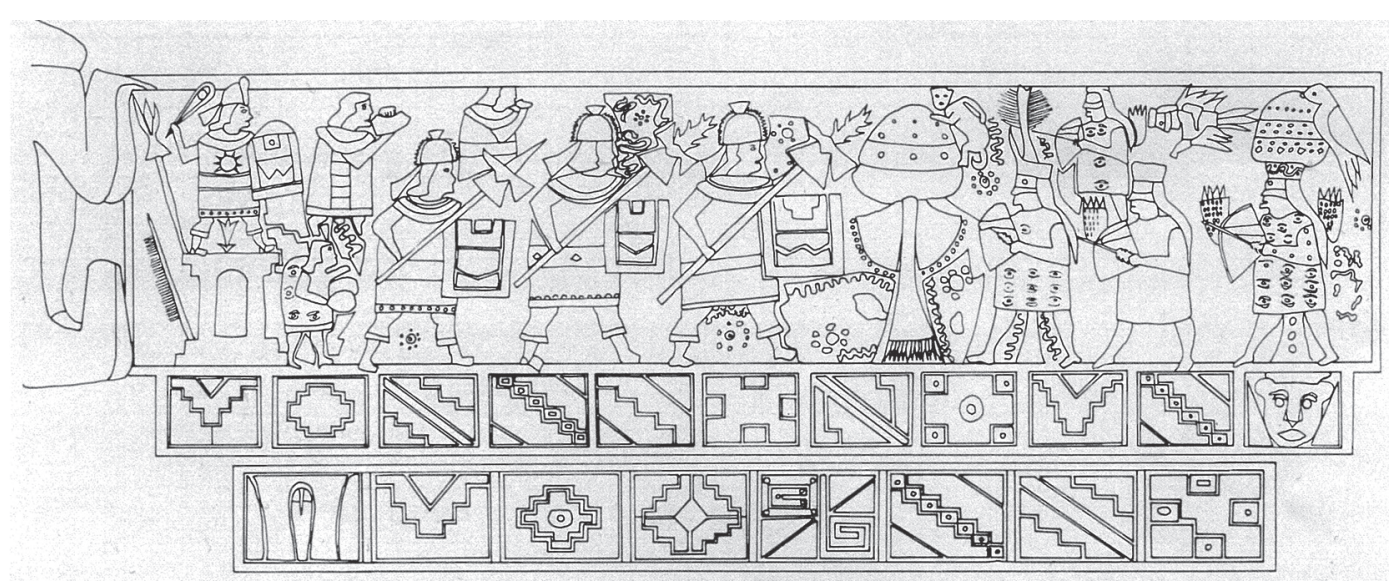

Fig. 3. Battle scene between Incas and Antis, XVIII century. Museo de America, Madrid. Source: Flores Ochoa; Arce; Argumedo (1998).

colonial perspective, the Antis were already the vanquished ones. Furthermore, in other Incas/ Antis battle scenes displayed on qeros, the Antis are even depicted as being killed, as prisoners or servants (Fig. 4) in a more direct and 'live' way of representing the Incas conquering the Antis. Alternatively, and conversely, it was a very direct way of demonstrating pictographically what happened with the Indians who refused Inca authority and rebelled against Inca power, such as the case of the Antisuyu Indians. Thus, in a way, these battle scenes portraying Antis as prisoners or being killed served simultaneously as
Inca propaganda and as a 'pedagogical' device in order to maintain peace and avoid insurgences.

Do these battle scenes between Incas and Antis represent any particular historical period in Andean history? As discussed elsewhere (Bertazoni 2007; Santos 1992; RenardCasevitz 1988), the Incas did manage to subjugate certain Antisuyu groups, albeit only to a limited extent. As Cieza de León (1985 [1553]: 120, XCV) and Santa Cruz de Pachacuti Yupanqui (1995 [1611]: 235-238) remind us, very often the Incas would not only fail in conquering the Antis, but would also be

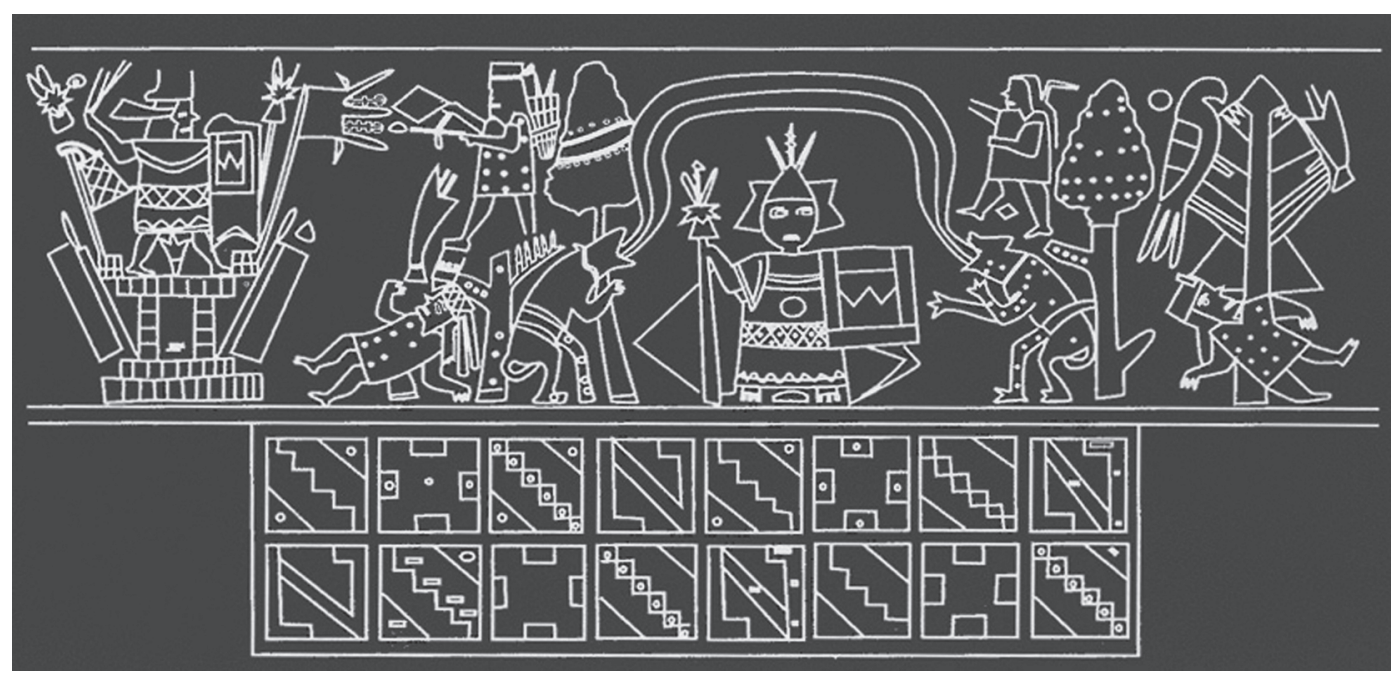

Fig. 4. Battle scene with the Incas killing Antis Indians, XVIII century. Museo Inka, Universidad Nacional del Cuzco. Source: Flores Ochoa; Arce; Argumedo (1998). 
defeated by them, being forced to withdraw quickly from Antis country on many occasions. Cieza de León narrates how frightened the Incas were of the ferocious [sic] Anti warriors as well as the huge snakes and jaguars that also inhabited the jungle. Thus there is here the presence of two contradictory elements. On one hand, qeros battle scenes where the Incas are clearly portrayed as superiors who always defeat the Antis. On the other, historical evidence of the opposite (the Antis defeating the Incas and therefore being in a superior position), suggesting a case of Inca propaganda and ideology - an idealised but unrealistic Inca outlook regarding the Antisuyu, the quarter (suyu) they had the most difficulty in conquering.

Still regarding the historicity of the battles found in Inca qeros, in a brief but interesting article, Teresa Gisbert (1999) discusses some qeros images and their relationship with the conquest of the Antisuyu. There, Gisbert analyses a colonial (eighteenth century) Callahuaya coffer, where she identifies the figures of both Inca Tupac Yupanqui and his father Pachacuti. The author concludes that this depiction in representing the Inca Emperors in the very process of conquering the Antisuyu indicates that some qeros (in this case a coffer) images in fact represent particular historical moments in the Inca period. The advantage for the Incas was that it was they who were producing the imagery; hence the fact that in the images they are always shown as the victors. Other important Inca historical moments were also depicted on colonial wooden vases - the Inca/Chanca war being an example.

However, there is one point which makes this matter more intricate: these scenes of Incas/Antis battles were made during colonial times or more specifically during the late seventeenth and early eighteenth centuries - a fact that inspires one to enquire whether it would have been possible that Inca Imperial propaganda or simply Inca culture and its history were still active even almost two centuries after the arrival of the Europeans. In this regard, we should remember that many centuries after 1532, ritual battles representing the historical fights between Atahualpa and his brother Huáscar or simply between different moieties still occur in several Andean communities (Cummins 2002: 251-252). Some of these ritual battles are so realistic that their participants are often hurt, sometimes fatally (Flores Ochoa 1998: 243). This suggests a long and strong pre-Hispanic tradition that endured, reinvented itself and continued to be a live and present element during the colonial period and continues even to this day. So strong and alive was Inca culture over colonial times that during the movement of extirpación de idolatrias, the Spaniards prohibited not only the borracheras ${ }^{9}$ but also tried to stop the production of qeros (Flores Ochoa 1998: 38). Inca colonial wooden vases and everything else that revived or celebrated Inca culture was seen as a threat to the colonial order and, from a Spanish perspective, it was imperative that they were extinguished.

Complementary interpretations help us to better understand the battle scenes on colonial qeros. For instance, Cummins (2002) suggests that these Inca/Antis scenes of combat represent ritual or mock battles which are a common element of Andean culture when different moieties would fight between themselves, as are also drinking competitions, when qeros would be used. Cummins' interpretation (1992: 255, 260) of these battle scenes converges with the idea of a complementary opposition between Incas and Antis, which represent Inca dominance over the forest Indians; a symbolic representation where culture and civilisation triumph over savagery and chaos, as well as being a visual version of the dichotomy opposition/reconciliation expressed in the duality between, respectively, hanan and hurin.

On continuing our analysis of Inca colonial qeros imagery, we shall move to another type of wooden vase that differs in form from the majority of vases. Most qeros

(9) Literally, borrachera would be translated as 'drunkenness'. However, the social activity of drinking together has a broader meaning in the Andean region. For a detailed discussion on the borracheras, see Saignes (1993). 
have an upside down trapezoidal format, where the base is always narrower than the top. The only time when qeros adopt an anthropomorphic shape is when the vases acquire the form of Amazonian Indians' heads (Figs. 2 and 5). This fact is extremely important for two reasons. Firstly, because it is only the Anti Indians who appear in this form when being represented on qeros. Collas, Chinchays or Condes are never represented anthropomorphically in qeros. This fact by itself is already significant because it suggests that, from a Cuzco viewpoint, the Antisuyu had a different position in relation to the other quarters of Tahuantinsuyu.

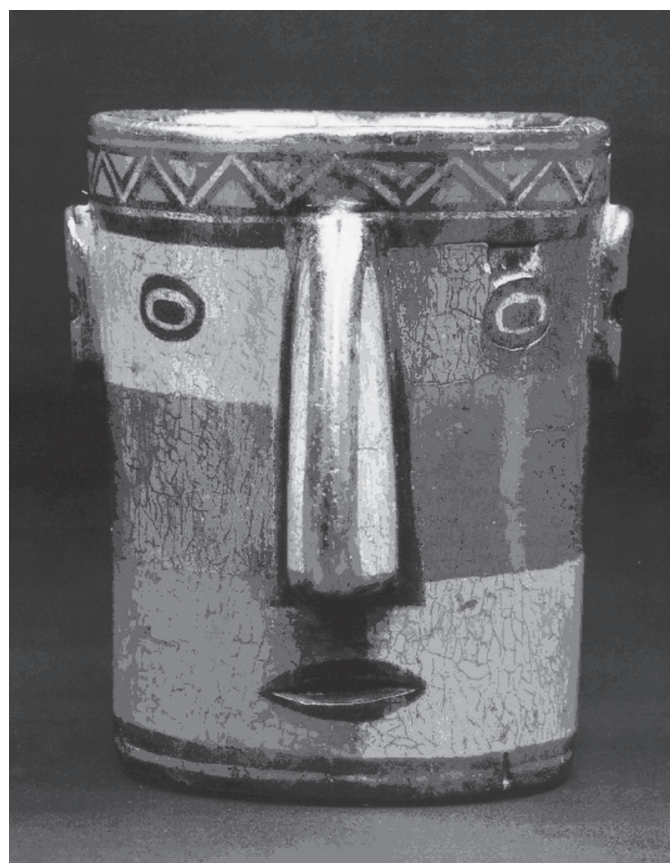

Fig. 5. Anthropomorphic qero shaped as a human (Amazonian Indian) head. XVIII century. Museo Inka, Universidad Nacional Mayor de San Marcos, Lima. Source: Flores Ochoa; Arce; Argumedo (1998: 185).

Secondly, because the act of drinking chicha in a vase in the shape of an Antis' head suggests a trophy-head relation where the one who wins a battle celebrates its victory by drinking from the symbolic decapitated head of the vanquished. According to Cummins, drinking from an Antis' anthropomorphic qero not only represented Inca victory over the
Antis, but also symbolised the transformations of disorder into order or the restitution of harmony (2002: 256). An alternative symbolism, I would suggest, would be a victory of culture over barbarism, of civilisation over savagery which is a dichotomy very often identified when discussing the Incas/ Antis relationship.

As for the qeros that adopt a zoomorphic shape of a jaguar's head (Fig. 6), I would include them in the same category as the Antis' head. As the Antis were associated with jaguars or otorongos, ${ }^{10}$ often being understood as synonymous.

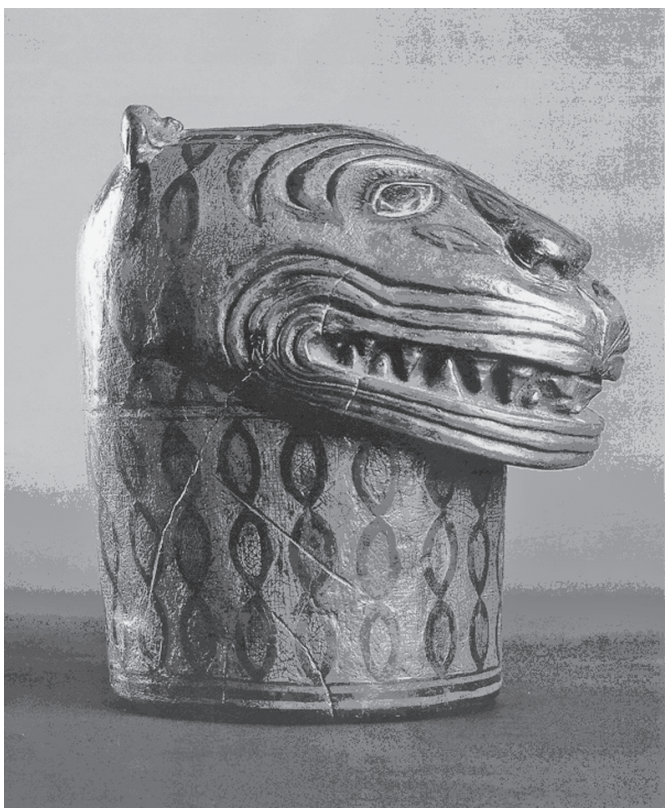

Fig. 6. Zoomorphic qero in the shape of a jaguar. Source: Flores Ochoa; Arce; Argumedo (1998: 136).

(10) Otorongo is the Quechua word for the jaguar. Otorongo Achachi was the sixth Inca captain who conquered parts of the Antisuyu. In one of Guaman Poma's images, Otorongo Achachi appears as a zoomorphic figure with the body of a jaguar and a face that is half jaguar and half humanoid. According to the chronicler, Otorongo Achachi was the son of Ynga Roca and in order to conquer the Antisuyu he was transformed into a jaguar and his child was born by a ch'unchu (synonymous with Antis) woman (Guaman Poma 1980 [c. 1613]: 119, 122). For more information on jaguar symbolism in the Americas see Benson, 1998. 
As suggested by Gisbert, qeros were a medium that the colonial Andean men employed in order to preserve their history and mythology, culture and traditions (1999: 95), in order to resist colonisation and, in the words of Cummins, "occupy a place of agency in colonial society in multiple and simultaneous ways" (2002: 5). Moreover, beyond Gisbert and Cummins' statements, I would also suggest that the combat images depicted in these Inca colonial wooden vases indicate that something reminiscent of Inca propaganda could still be identified even during the late seventeenth and early eighteenth centuries. This suggests that even about two centuries after the arrival of the Spaniards, reverberations of what was once the Inca/Antis relationship could still be noticed. Alternatively, as similarly stated by Cummins, "the colonial quero [sic], with figures carved and painted into its surface, came to materialize, among other things, Andean memory, conjuring an image of the pre-Hispanic Inca for the colonial viewer" (Cummins 2002: 2). Additionally, I would argue that in the case of the Antisuyu, it was precisely because the Incas did not manage to completely conquer the western Amazonian territory that battle images between Incas and Antis are so abundant in colonial qeros.

\section{Conclusions}

The analysis of the qeros imagery suggests that some pre-Hispanic patterns regarding the Incas/Antis relationship manifest themselves in different ways and formats during the colonial era. It indicates that some pre-Colombian structures continued to exist even after many centuries and despite several changes in Andean society caused by the new colonial order. $^{11}$
Besides, as a live organism which interacts and is in dialogue with its own times, Andean culture has also incorporated new elements. In the case of the colonial qeros, these new additions are represented by a new method of visual communication: if during Inca times it was via abstract symbols, during the colonial era a new format was required since with the Spaniards, there was now a new audience to cater for. Thus, with the requirement of a new visual layout, Inca colonial qeros incorporated the use of figurative images into its body of visual representations.

Essentially, the analysis of Inca colonial qeros suggests that despite colonisation and its upheavals, the history of the Incas together with its pre-Colombian elements continued to play a critical part during colonial times thanks, fundamentally, to indigenous agency. The matter not only concerns the persistency of indigenous traditions throughout the postcolonial world, but also how the Indians made use of pre-Colombian traditions and mental structures for their own convenience in order to accommodate, resist and survive within the new state of affairs imposed by the Spaniards. On the whole, it concerns both native resistance and resilience; reinventions and interpretations of the past in order to better fit in the new panorama brought by the conquest.

It was indeed through media such as the qeros vases that the Incas could express themselves and find their place within colonial society. Telling their history and most importantly, the continuity thereof, was vital in reinforcing their presence and active participation at the forefront in the new order of things. Rather than showing the natives as passive recipients of European traditions, what the investigation of qero imagery shows is indigenous agency responding to the socio-economic changes initiated in 1532 . 
BERTAZONI, C. Representations of western Amazonian indians on Inca colonial qeros. Revista do Museu de Arqueologia e Etnologia, São Paulo, 17: 321-331, 2007.

\begin{abstract}
This article proposes to put together an iconographical analysis of Inca colonial qeros, offering an insight into Inca history where one can observe, in visual format, one of the media of expression the Incas used in order to disseminate their values and traditions and, in the ultimate instance, their ideology. A remarkable number of qeros portray scenes of battle between Incas and western Amazonian Indians (or Antis), often with Amazonian fauna and flora forming a backdrop. It seems that from all the four corners of Tahuantinsuyu, the Antisuyu (the Amazonian part of the Inca empire) is the quarter that holds a very special place when it comes to the imagery on Inca wooden vases known as qeros. Bearing this in mind, we shall analyse some of these wooden vases in order to better understand the images of the Antisuyu and its inhabitants which the Incas chose to project through this particular medium.
\end{abstract}

Keywords: Incas - Antisuyu - Western Amazonia - Qeros.

\title{
Sources
}

CIEZA DE LEÓN, P.

1985[1553] La Crónica del Peru. Las Guerras Civiles Peruanas. Madrid: Momumenta HispanoIndiana.

GUAMAN POMA DE AYALA, F.

1980[c. 1613] El Primer Nueva Corónica y Buen Gobierno. México: Siglo Veintiuno.

JUAN DE SANTA CRUZ PACHACUTI

1995[1611] Relación de Antiguidades de Este Reino del Perú. Edición, Índice Analítico y Glosario de Carlos Araníbar. Lima: Fondo de Cultura Económica.
TITU CUSI YUPANGUI

1985[1570] Ynstruçion del Ynga Don Diego de Castro Titu Cusi Yupangui para el muy Ilustre Señor el Liçençiado Lope Garçia de Castro, Governador que fue destos Reynos del Piru, Tocante a los Negoçios que con su Magestad, en su Nonbre, por su Poder a de Tratar; la qual es esta que se sigue. Introducción de Luis Millones. Lima: Ediciones El Virrey.

\section{References}

BENSON, E.

1998 The Lord, the Ruler: Jaguar Symbolism in the Americas. In: Saunders, N. (Ed.) Icons of Power Feline Symbolism on the Americas. London, Routledge: 53-76.

BERTAZONI, C.

2007 Antisuyu: An Investigation of Inca Attitudes to their Western Amazonian Territories. Unpublished PhD Thesis. University of Essex, UK.

BOONE, E.H.; CUMMINS, T. (Eds.)

1998 Native Traditions in the Postconquest
World. Washington, DC: Dumbarton Oaks.

CUMMINS, T.

1992 The Uncomfortable Image: Pictures and Words in the Nueva Corónica y Buen Gobierno. In: Adorno, R. (Ed.) Guaman Poma de Ayala. The Colonial Art of an Andean Author. New York, Americas Society/Art Gallery: 46-59.

2002 Toasts with the Inca: Andean Abstraction and Colonial Images on Quero Vessels. 
Ann Harbor: University of Michigan Press.

FLORES OCHOA, J; ARCE, E.; ARGUMEDO, R. 1998 Qeros. Arte Inka en Vasos Ceremoniales. Lima: Colección Arte y Tesoros del Peru.

GISBERT, T.

1999 La Serpiente Amaru y la Conquista del Antisuyu: Una Historia Alternativa. In: T. Gisbert, T. (Ed.) El Paraíso de los Pájaros Hablantes. La Imagen del Otro en la Cultura Andina. La Paz, Universidad Nuestra Señora de La Paz, Plural: 85-95.

GOMES, D.M.C.

2002 Cerâmica Arqueológica da Amazônia: Vasilhas da Coleção Tapajônica MAE-USP. São Paulo: EDUSP.

OSSIO, J.M. (Ed.)

1973 Ideología Mesiánica del Mundo Andino. Lima: Edición de Ignacio Prado Pastor.

RENARD-CASEVITZ, F.M., SAIGNES, T.; TAYLOR, A.C.

1988 Al Este de los Andes. Ensayo sobre las Relaciones entre las Sociedades Amazónicas y Andinas entre los Siglos XV y XVII. Tomos I-II. Quito: Ediciones Abya-Yala and IFEA. ROWE, J.H.

1992 La Cronología de los Vasos de Madera
Inca. Arqueología de Cuzco. Cuzco, Instituto Nacional de Cultura: 97-136.

SAIGNES, T.

1981 El Piedemonte Amazónico de los Andes Meridionales: Estado de la Cuestión y Problemas Relativos a su Ocupación en los Siglos XVI y XVII. Boletin del Institut Francés de Estudios Andinos, X (34): 141-176.

1985 Los Andes Orientales: Historia de un Olvido. Instituto Francés de Estudios Andinos de la Realidad Económica y Social, Cochabamba.

1993 Borrachera y Memoria: la Experiencia de lo Sagrado en los Andes. Peru: IFEA.

SANTOS, F.

1992 Etnohistoria de la Alta Amazonía. Siglos XVI-XVIII. Quito: Editora Abya-Yala.

TAYLOR, A.C.

1992 História Pós-Colombiana da Alta Amazônia. In: Carneiro da Cunha, M. (Org.) História dos Índios no Brasil. São Paulo Cia das Letras: 213-238.

1999 The Western Margins of Amazonia from the Early Sixteenth to Early Nineteenth Century. In: Salomon, F.; Schwartz, S.B. (Eds.) The Cambridge History of Native Peoples of Americas, South America III (2). Cambridge, Cambridge University Press: 188-256. 